\title{
First meconium time may be a predictive factor for infantile colic: a prospectivestudy
}

\section{Illk mekonyum zamanı infantil kolik için bir prediktif faktör olabilir: prospektif bir çalışma}

Hakan Aylanç ${ }^{1}$,Nazan Kaymaz ${ }^{1}$, Şulle Yıldırım ${ }^{1}$, Sibel Cevizci² ${ }^{2}$ Güilşen Vururur ${ }^{1}$, Fatih Battal ${ }^{1}$

${ }^{1}$ CanakkaleOnsekiz Mart University, Faculty of Medicine, Department of Pediatrics, Canakkale, Turkey

${ }^{2}$ CanakkaleOnsekiz Mart University, Faculty of Medicine, Department of Public Health, Canakkale, Turkey

Corresponding author:Hakan Aylanç, MD., Department of Pediatrics, Canakkale Onsekiz Mart University, Faculty of M edicine, Canakkale, Turkey. E-mail:hakanaylanc@comu.edu.tr

Received/Accepted:December 14, 2017 / April 06, 2018

Conflict of interest: There is not a conflict of interest.

\section{SUMMARY}

Objective: Meconium passage is a good marker of a normal gastrointestinal tract and the general health of a neonate. There are both gastrointestinal and non-gastrointestinal hypotheses for the etiology of infantile colic. The aim of the present study was to determine whether first meconium time could predict infantile colic (IC) later.

Method: A follow-up study was conducted with 248 consecutive singleton full-term healthy neonates. The demographic variables, age at first feed, time of first meconium, number of feeds until the first meconium, and number of defecations during the first 3 days of life were recorded. The characteristics of the neonates were analyzed for association with IC.

Results: First meconium time was $9.7 \pm 10.2 \mathrm{~h}$ and $6.8 \pm 7.8 \mathrm{~h}$ in the IC and non-IC groups, respectively $(\mathrm{p}=0.014)$. The risk of IC was increased by 1.99 times for those who did not have their first meconium until $5.75 \mathrm{~h}$ after birth (95\% CI: 1.13-3.51) and by 2.11 times for those who did not have more than 17 defecations in the first $72 \mathrm{~h}$ (95\% CI: $1.19-3.74)$. Conclusions: Neonates who do not have their first meconium in the first $5.75 \mathrm{~h}$ after birth and who have fewer than 17 defecations in the first $72 \mathrm{~h}$ of life are at risk of IC development.

Keywords: Colic; crying; stool; infant; newborn.

\section{ÖZET}

Amaç: Mekonyum pasaj1 yenidoğanın genel sağlık durumunun ve gastrointestinal sistemin bütünlüğünün iyi bir göstergesidir. Infantil koliğin etiyolojisinde gastrointesitinal ve gastrointestinal olmayan hipotezlerin ikisi de vardır. Bu çalışmanın amacı ilk mekonyum zamanının infantile kolik gelişimini öngörüp öngöremeyeceğini belirlemekti.

Yöntem: Çalışma ardışık doğan 248 sağlıklı term, tekiz yenidoğan ile yürütüldü. Demografik değişkenler, ilk beslenme zamanı, ilk mekonyum zamanı, ilk mekonyuma kadar beslenmesayısı ve yaşamın ilk 3 günü boyunca defekasyon sayısı kaydedildi. Yenidoğanların özellikleri infantile kolik ile ilişkisi açısından analiz edildi.

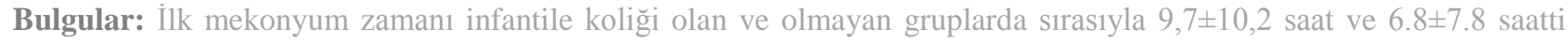
( $\mathrm{p}=0,014)$. Infantil kolik riski doğumdan sonra 5,75 saate kadar ilk mekonyum çıkışı olmayanlarda 1,99 kat (\%95 CI: 1,13-3,51) ve ilk 72 saatte 17 'den fazla defekasyonu olmayanlarda 2,11 kat (\%95 CI: 1,19-3,74) artmış olarak saptandı. Sonuç: Doğum sonrası ilk 5,75 saatte ilk mekonyumunu çıkarmayan ve ilk 72 saatinde dişkılama sayısı 17'den az olan yenidoğanlar için infantile kolik gelişme riski vardır.

Anahtar sözcükler: Kolik; ağlama; dışk1; infant; yenidoğan. 


\section{INTRODUCTION}

Meconium passage is a good marker of a normal gastrointestinal tract and the general health of a neonate ${ }^{1}$. In some conditions, such as Hirschsprung's disease, meconium ileus and intestinal atresia, the passage of meconium is absent or delayed. Delayed or non-passage of the meconium should alert clinicians, and comprehensive rectal examinations should be performed on all neonates that have not passed meconium in $48 \mathrm{~h}^{2}$. However, in preterm and very low birth weight neonates, meconium passage may be delayed due to delayed maturation of gut motor mechanisms ${ }^{3}$.

Infantile colic (IC) was defined by Wessel et al ${ }^{4}$ in 1954 as episodes of extreme crying in the afternoon or evenings without definite reason for more than 3 hours a day, more than 3 days a week, and lasting longer than 3 weeks. These babies are otherwise healthy and growing well. There are both gastrointestinal and non-gastrointestinal hypotheses for its etiology. The gastrointestinal hypothesis argues for food allergies, abnormal peristalsis, excessive gas formation, and immature gut function ${ }^{5,6}$. Some accompanying symptoms, such as constipation or diarrhea, vomiting, and abdominal distension support the gastrointestinal hypothesis ${ }^{7}$. On the other hand, the treatment is also controversial and there are many studies on this topic that investigate effectiveness of dietary, pharmacological, behavioral and complementary therapies ${ }^{8}$. Pharmacological agent; for example, simethicone, one of the most well-known pharmacological approaches, comforts the infant by increasing bowel movements and reducing gas formation, making the gastrointestinal hypothesis more likely whereas others found no difference in gastrointestinal symptoms ${ }^{9,10}$. Recent studies have focused the role of microbiota in the pathogenesis of this disturb and so new treatments, such as probiotics, have been proposed ${ }^{11}$.

The present study aimed to investigate describing meconium patterns in neonates with IC, a possible association between meconium patterns and IC, and try to use first meconium time to predict which neonates will develop IC.

\section{MATERIAL AND METHODS}

\section{Study population}

A prospective study was conducted with 248 consecutive singleton full-term healthy neonates (gestational age 37-42 weeks) delivered at Çanakkale Onsekiz Mart University Hospital.
Criteria for exclusion were admitted to the neonatal intensive care unit (NICU) at any time, mothers with complicated labor or chronic disease (including diabetes, hypertension, asthma, endocrine disease, metabolic disease, inflammatory disease, and hyperthyroidism), eclampsia or preeclampsia, oligo/polyhydramnios, or pre- or intrapartum drug use (narcotics, antibiotics, magnesium sulfate, steroids, etc.), pregnants who had general or epidural anesthesia, babies delivered by emergency caesarean section $(\mathrm{C} / \mathrm{S})$, and cases with meconium-stained amniotic fluid..

\section{Data collection and study design}

On the first part of the questionnaire, maternal demographic variables were collected, on the second part, neonate variables were recorded. The third part recorded the ToFM, age at first feed, number of feeds from birth to time of first meconium, and total number of defecations during the first 3 days of life. The resident doctor and nurse in charge of the patient obtained the data by checking the neonates' diaper every $2 \mathrm{~h}$. Families were also instructed not to use any drug or traditional application for preventing IC before the first meconium. Frequency of meconium passage was recorded by the sum of meconium passages during hospitalization and the parents' report of the numbers after discharge until $72 \mathrm{~h}$ of life. There was not any missing data in terms of this subject. Follow-up for IC was done through phone contact for 3 months due to the fact that IC mostly remits by the age of 3 months so this was an appropriate amount of time in order not to miss a significant number of colicky infants ${ }^{13,14}$. The same nurse who was trained on performing the questionnaire's fourth part made the phone calls at monthly intervals during the 3 months. Mothers were asked, "Does your baby have persistent crying attacks?" If the answer was "no," the infant was included in control group. If the answer was "yes," the second question included components of Wessel's criteria ${ }^{4}$. The question asked if: i) the baby cries more than 3 hours a day, ii) more than 3 days a week, and iii) whether this has lasted longer than 3 weeks. The mothers were instructed not to consider episodes of crying for other reasons, such as hunger, fatigue, or short-term attacks. Infants diagnosed with IC were called in for evaluation at the hospital outpatient clinic, for a differential diagnosis of IC. A total of 81 patients came to the hospital for a physical examination and 22 did not, explaining that they had already been examined by pediatricians and prescribed medical treatment for IC. The total number of children with IC who needed drug intervention for control was 69 , not including the 
22 patients mentioned above. All of the participants met Wessel's criteria and had been investigated by a pediatrician to exclude all other potential differential diagnosis (diaper changes, otitis media, urinary infection, neonatal abstinence syndrome, thrush, heart failure, supraventricular tachycardia, gastrointestinal obstruction, constipation, anal fissures, inguinal hernia, gastroesophageal reflux disease, urinary tract infection, feeding intolerance, vomiting, abdominal distension, fussiness/ irritability skeletal-fracture, fever, abusive head trauma, meningitis). The patients who met less than 3 criteria $(n=12)$ were considered as Non-WesselColicky infants and noted to have no IC. At followup, 4 infants who were not accessible were excluded from the study. As a result, of 301 consecutive neonates, 248 neonates were entered into this study (Figure 1). The establishment of the study was approved by the Çanakkale Onsekiz Mart University Science Ethical Committee and was performed in accordance with the Declaration of Helsinki. Informed consent was obtained from all participants.

\section{Statistical analysis}

Statistical analyses were performed using SPSS software version 19.0 (IBM Armonk, NY). The variables were investigated using visual and

\section{RESULTS}

A total of 301 infants were born during the study period. Among these infants, 41 were excluded because of admitted to the NICU $(n=6)$, born before gestational age 37 weeks $(n=8)$, mothers with complicated labor ( $\mathrm{n}=3$, one of umbilical cord entanglement and two of dystocia) or chronic disease $(n=8)$, eclampsia or preeclampsia $(n=2)$, oligo/polyhydramnios, or pre- or intrapartum drug analytical methods (Kolmogorov-Simirnov) to determine whether or not they were normally distributed. Descriptive analyses were presented using frequencies, percentages, means, standard deviations, and minimum and maximum for normally distributed variables. The Chi-square test was used to compare these proportions in different groups. Comparisons between the two groups were made using the two independent-samples t-test. To define the cutoff value for ToFM and number of defecations in the first $72 \mathrm{~h}$ of life, ROC curve analysis was used. We used Multiple logistic regression (Backward stepwise conditional method) analysis to control for confounding and to examine the strength of the risk related to significant explanatory variables. Logistic regression analysis was used to examine the influence of independent variables (gestational age at birth in weeks, delivery mode, ToFM, and number of stools in the first $72 \mathrm{~h}$ ) upon the dependent variable (IC). Logistic regression (Backward stepwise method) was used, as well as odds ratios (ORs) to evaluate risk factors associated with IC. Hosmer-Lemeshow goodnessof-fit statistics were used to assess model fit. A 5\% type I error level was used to infer statistical significance.

use $(\mathrm{n}=3)$, neonates delivered by emergency $\mathrm{C} / \mathrm{S}$ $(n=4)$, and cases with meconium-stained amniotic fluid $(n=3)$. The pregnants who had general $(n=1)$ and epidural anesthesia $(n=3)$ were excluded because of the small number. A total of 248 neonates were enrolled in the study (Figure 1). There were 91 neonates in IC group and 157 neonates in non-IC group. Table 1 shows the relationship between patients' characteristics and time of first meconium. 
Table 1. Relation between patients' characteristics and time of the first meconium

\begin{tabular}{|c|c|c|c|c|}
\hline \multicolumn{5}{|c|}{ Time of thefirstmeconium (hr) } \\
\hline & $0-12 \mathrm{hr}$ & $13-24 \mathrm{hr}>25 \mathrm{hr}$ & & $\mathbf{p}$ \\
\hline Sex & $\mathbf{N}(\%)$ & $\mathbf{N}(\%)$ & $\mathbf{N}(\%)$ & \multirow{3}{*}{0.066} \\
\hline Male & $100(49.0)$ & $24(66.7)$ & $5(62.5)$ & \\
\hline Female & $104(51.0)$ & $12(33.3)$ & $3(37.5)$ & \\
\hline \multicolumn{5}{|l|}{ Delivery mode } \\
\hline$N V D$ & 79(38.7) & $7(19.4)$ & $4(50.0)$ & \multirow{2}{*}{0.835} \\
\hline$C / S$ & $125(61.3)$ & $29(80.6)$ & $4(50.0)$ & \\
\hline \multirow{2}{*}{\multicolumn{5}{|c|}{$\begin{array}{l}\text { FeedingtypebeforeToFM } \\
\text { Breastmilk }\end{array}$}} \\
\hline & & & & \\
\hline Formula & $106(52.0)$ & $17(47.2)$ & $2(25.0)$ & \multirow[t]{4}{*}{0.713} \\
\hline Combination & $3(1.5)$ & $3(8.3)$ & & \\
\hline \multirow[t]{2}{*}{ To FM without feeding } & $42(20.6)$ & $16(44.4)$ & $6(75.0)$ & \\
\hline & $53(26.0)$ & 0 & 0 & \\
\hline
\end{tabular}

P:The Chi-Square Test, NVD: Normal vaginal delivery, C/S: C/, ToFM: Time of firstmeconium

Table 2. Perinatal and delivery history of newborns in the groups

\begin{tabular}{|c|c|c|c|}
\hline & $\begin{array}{r}\text { IC group }(\mathbf{n}=91) \\
\mathbf{N}(\%)\end{array}$ & $\begin{array}{c}\text { Non-IC group }(\mathrm{n}=157) \\
\mathbf{N}(\%)\end{array}$ & $\mathbf{p}$ \\
\hline $\begin{array}{l}\text { Sex } \\
\quad \text { Male } \\
\quad \text { Female } \\
\end{array}$ & $\begin{array}{l}46(50.5) \\
45(49.5) \\
\end{array}$ & $\begin{array}{l}83(52.9) \\
74(47.1)\end{array}$ & 0.725 \\
\hline $\begin{array}{l}\text { Gestational age at birth } \\
\text { (wk) } \\
37-40 \\
>40\end{array}$ & $\begin{array}{l}77(84.6) \\
14(15.4)\end{array}$ & $\begin{array}{c}106(67.5) \\
51(32.5)\end{array}$ & $\begin{array}{c}\mathbf{p}^{*} \\
0.004\end{array}$ \\
\hline $\begin{array}{l}\text { Delivery mode } \\
N V D \\
C / S\end{array}$ & $\begin{array}{l}25(27.5) \\
66(72.5)\end{array}$ & $\begin{array}{l}65(41,4) \\
92(58,6)\end{array}$ & $\begin{array}{c}\mathrm{p} \\
0.028\end{array}$ \\
\hline $\begin{array}{l}\text { Birth weight }(\mathrm{g}) \\
<2500 \\
2500-4000 \\
>4000 \\
\end{array}$ & $\begin{array}{l}11(12.1) \\
78(85.7) \\
2(2.2) \\
\end{array}$ & $\begin{array}{c}14(8.9) \\
137(87.3) \\
6(3.8) \\
\end{array}$ & 0.588 \\
\hline $\begin{array}{l}\text { ToFM time } \\
\text { In the delivery room } \\
\text { The others }\end{array}$ & $\begin{array}{l}12(13.2) \\
79(86.8)\end{array}$ & $\begin{array}{c}33(21.0) \\
124(79.0)\end{array}$ & 0.123 \\
\hline & Mean \pm SD (min-max) & Mean \pm SD (min-max) & $\mathbf{p}^{* *}$ \\
\hline $\begin{array}{l}\text { Total number of feeds } \\
\text { before ToFM }\end{array}$ & $4.45 \pm 3.8(1-20)$ & $3.60 \pm 3.11(1-21)$ & 0.091 \\
\hline $\begin{array}{l}\text { Feeding type before } \\
\text { ToFM } \\
\text { Breastmilk }^{\text {F }} \\
\text { Formula } \\
\text { Combination }\end{array}$ & $\begin{array}{c}\mathbf{n}(\%) \\
42(46.2) \\
2(2.2) \\
33(36.3)\end{array}$ & $\begin{array}{c}\mathbf{n}(\%) \\
83(52.9) \\
4(2.5) \\
31(19.7)\end{array}$ & 0.029 \\
\hline
\end{tabular}

NVD: Normal vaginal delivery, C/S: Caesarean Section, ToFM: Time of firstmeconium, p:TheChi-square test, $\mathrm{p}^{*}$ :Fisher'sExact Test, $\mathrm{p}^{* *}$ : TwoIndependent-Sample t-test, \%: percent of thecolon, a: data of 53 newbornswere not includedintotheanalysesbecausethey had done theirfirstmeconiumbefore feding. 


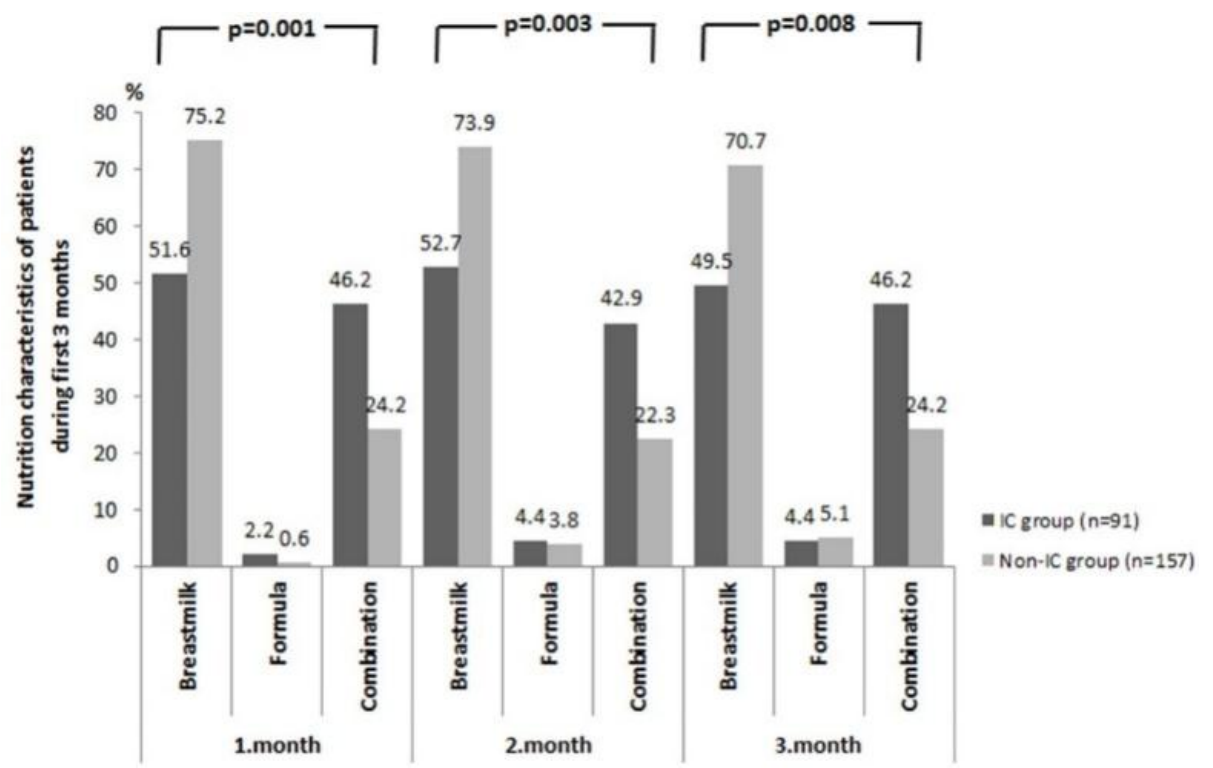

Figure 1. Flow chart of the selection of a study sample from mothers delivered at Çanakkale Onsekiz Mart University Hospital. All analyses presented in this paper are based on 248 healthy infants.

Two hundred and forty (97\%) of our subjects passed their first meconium within $24 \mathrm{~h}$ and an additional 8 (3\%) did in $48 \mathrm{~h}$. Mean first meconium time in the study group was $7.9 \pm 8.9 \mathrm{~h}$. It was $7.4 \pm 9.4 \mathrm{~h}$ and $8.3 \pm 9.4 \mathrm{~h}$ for female and male neonates, respectively $(\mathrm{p}=0.451)$. First meconium time was $9.7 \pm 10.2 \mathrm{~h}$ and $6.8 \pm 7.8 \mathrm{~h}$ in the IC and non-IC groups, respectively ( $\mathrm{p}=0.014$ ) (Figure 2 ). The mean number of defecations in the first $72 \mathrm{~h}$ of life was found to be significantly different in patients with IC, as shown in Figure $3(\mathrm{p}=0.001)$. Mean first meconium time was $7.7 \pm 7.6 \mathrm{~h}$ in neonates born at $37-40$ weeks, and $5.4 \pm 7.8 \mathrm{~h}$ in neonates born after 40 weeks $(\mathrm{p}=0.048)$. The mean number of defecations in the first $72 \mathrm{~h}$ of life was 17.4 \pm 5.2 (minimum 3, maximum 32) for all patients in the study.

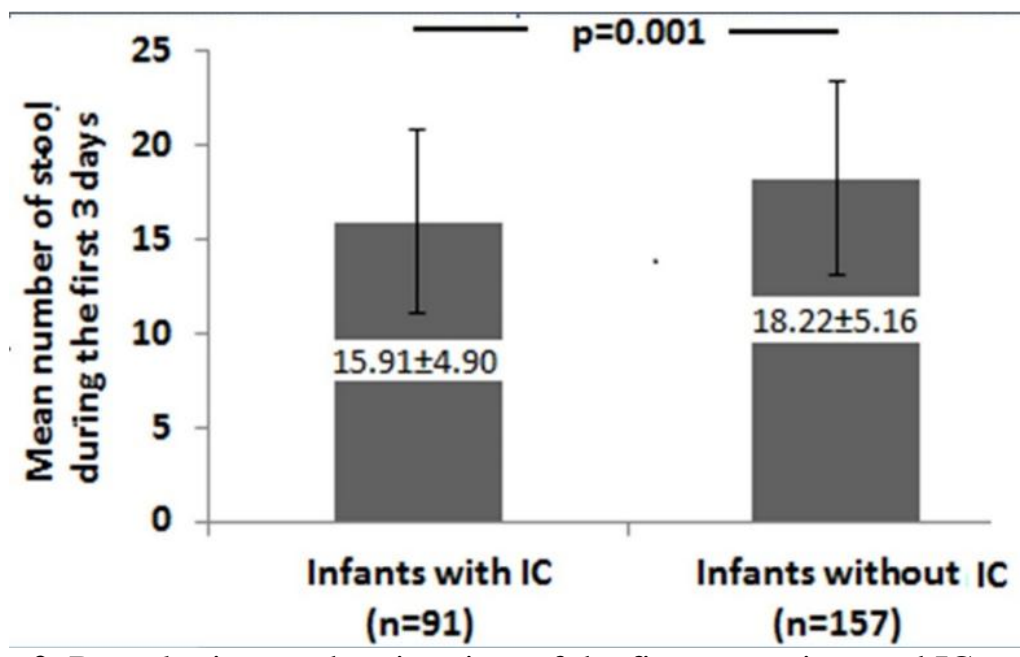

Figure 2. Box plot image showing time of the first meconium and IC presence 


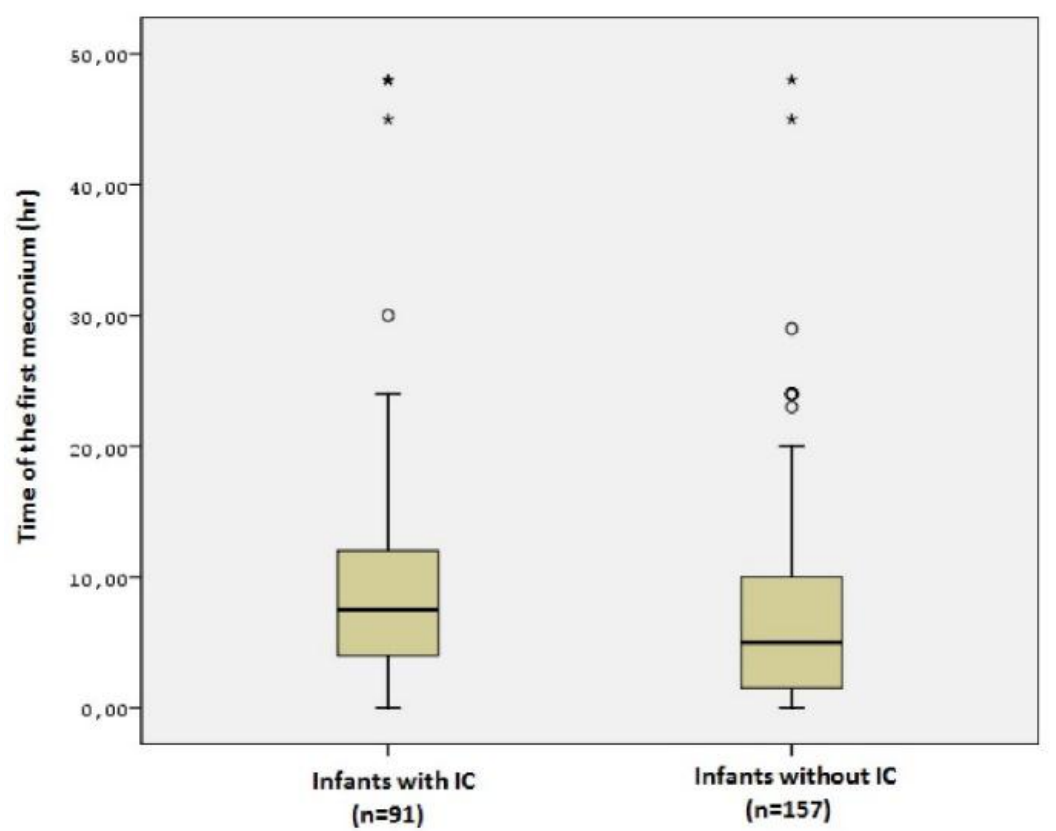

Figure 3. Bar graph image showing mean number of defecation in the first $72 \mathrm{~h}$ of life and IC presence.

IC was seen in 91 neonates ( $37 \%$ ). The perinatal and delivery history of neonates in the IC and nonIC groups are shown in Table 2.
More infants in the non-IC group were found to be breastfed compared to infants in the IC group (Figure 4).

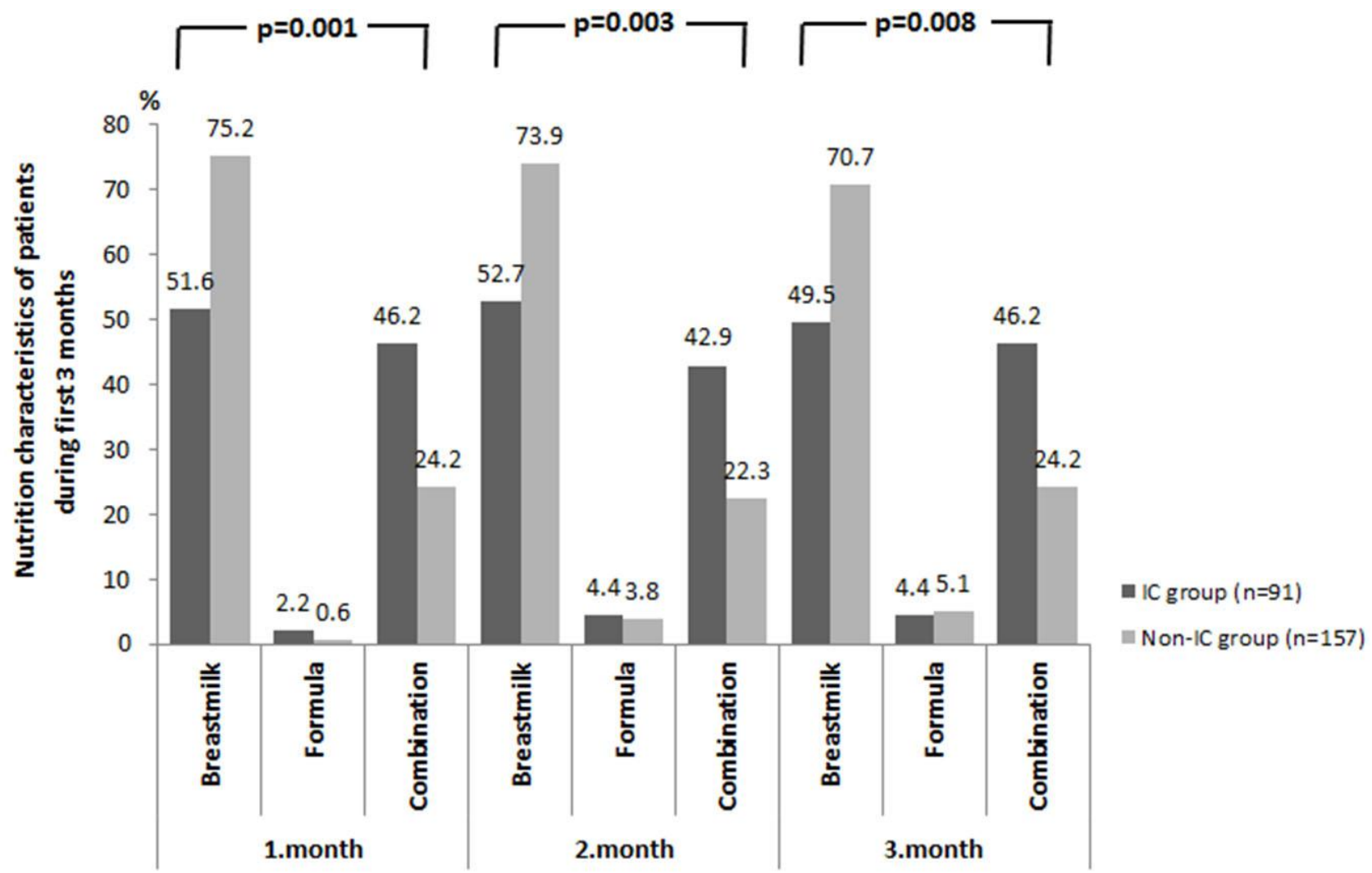

Figure 4. Nutrition characteristics of infants during first 3 mo of life in the groups. 
According to backward stepwise (conditional) logistic regression analysis results, the fit-to-model test of the data was valid (Nagelkerke R Square: 0.101, Hosmer-Lemeshow: $\mathrm{p}=0.058$ ). According to multivariate analysis results, the risk of IC was increased by 1.99 times for those who did not have their first meconium until $5.8 \mathrm{~h}$ after birth $(95 \% \mathrm{CI}$ :
1.13-3.51), and by 2.1 times for those who did not have more than 17 defecations in the first $72 \mathrm{~h}$ (95\% CI: 1.19-3.74) (Table 3).

Table 3. Regressioncoefficientsandoddsratios (95\% CIs) for risk factorsassociatedwith IC.

\begin{tabular}{lcccc}
\hline & $\boldsymbol{\beta}$ value & OR & CI 95\% & $\boldsymbol{p}^{*}$ \\
\hline Constant & -1.663 & 0.225 & - & $<\mathbf{0 . 0 0 1}$ \\
\hline Gestational age at birth (wk) & & & & \\
\hline $\begin{array}{l}37-40(1) \\
>40(0)\end{array}$ & 0.647 & 0.523 & $0.265-1.035$ & 0.063 \\
\hline Delivery mode & & & & \\
\hline $\begin{array}{l}\text { NVD (0) } \\
\text { C/S (1) }\end{array}$ & 0.108 & 1.114 & $0.592-2.094$ & 0.738 \\
\hline $\begin{array}{l}\text { ToFM (h) } \\
\leq 5.75(0)\end{array}$ & & & \\
$>5.75(1)$ & 0.688 & $\mathbf{1 . 9 8 9}$ & $1.128-3.506$ & $\mathbf{0 . 0 1 7}$ \\
\hline $\begin{array}{l}\text { Number of defecation in the first 72 } \\
\text { h of life }\end{array}$ & & & & \\
\hline $\begin{array}{l}\geq 16.5(0) \\
<16.5(1)\end{array}$ & 0.745 & $\mathbf{2 . 1 0 6}$ & $1.185-3.742$ & $\mathbf{0 . 0 1 1}$ \\
\hline
\end{tabular}

*Backward stepwise logistic regression analysis; OR: Oddsratio; CI: Confidence interval; ToFM: Time of firtme conium. The last model was presented in thisTable. Variable(s) entered on step 1: type of feeding, type of delivery, gestationalage at birth in weeks, ToFM, andnumber of stools in thefirst $72 \mathrm{~h}$.

\section{DISCUSSION}

The present study indicates that infants with IC had significantly delayed ToFM compared to infants without IC, and they had fewer defecations in the first $72 \mathrm{~h}$ of life. Our results showed that neonates who do not have their first meconium in the first $5.8 \mathrm{~h}$ after birth and who have fewer than 17 defecations in the first $72 \mathrm{~h}$ of life are at risk of IC development.

Intrauterine development of intestinal motility is not very well understood. In previous studies, intestinal dysmotility, particularly hypermotility, had been implicated as one of the pathogeneses of $\mathrm{IC}^{6}$. Motilin levels, which cause increased intestinal motility, were found to be raised in infants who develop IC ${ }^{15}$. However, we did not examine the number of dairy stools during the first months of life. Our study's findings showed that the mean number of meconium stools in the first 72 $\mathrm{h}$ of life was lower in neonates with IC and this may indicate that hypomotility may be more responsible than hypermotility as an etiological factor for IC.

Most babies have their first meconium during the first $48 \mathrm{~h}$ of life in our study similar to literature ${ }^{16}$. In the present study sex and birth weight had no impact on the ToFM, similar to a recent study by
Okoro et al. ${ }^{17}$ However, most neonates who had their ToFM after $24 \mathrm{~h}$ were male. On the other hand, low birth weight (LBW) neonates were found to have delayed ToFM in other studies ${ }^{18,19}$. Although the number of neonates with birth weight $<2500 \mathrm{~g}$ or $>4000 \mathrm{~g}$ was small in the present study, these patients had their ToFM more often within the first $12 \mathrm{~h}$ after birth. Contrary to our results, LBW neonates and those born with a weight high for gestational age were found to have delayed ToFM compared to neonates with normal birth weight in earlier studies ${ }^{20,21}$. In preterm babies, the delayed ToFM is suggested to be due to interrupted developmental maturation of bowel function, resulting in intestinal hypomotility ${ }^{22}$. We did not include preterm babies in our study. Evaluating our findings in terms of gestational age, no difference was found in ToFM time. There was also no difference in time to ToFM between vaginally born and C/S-born neonates in our study. Tateishi et al. 23 examined this relationship and found that neonates born vaginally passed their first meconium earlier compared to those born by $\mathrm{C} / \mathrm{S}$. The other factor affecting ToFM was feeding type. Metaj et al. ${ }^{24}$ did not find any association between ToFM and first feeding age or feeding type. In the present study, $21 \%$ of neonates passed their first 
stool prior to any type of feeding and the ToFM was found not to be affected by the form of nutrition.

IC was seen in $37 \%$ of all infants in our study, similar to the rate reported in previous studies ${ }^{25,26}$. This rate range is largely dependent on reasons such as the subjectivity of IC, societal differences, and the structure of the study ${ }^{27}$. Our study has an advantage in this sense, as it was conducted prospectively. Considering factors affecting IC, LBW was found to be associated with IC ${ }^{28}$. The percentage of LBW neonates was higher in the present study in the IC group but this was not statistically significant. Another factor that may trigger IC in the study is to be borne by $\mathrm{C} / \mathrm{S}$. This may be due to incomplete maturity of the gut, and contradicts some previous studies ${ }^{29}$. Also, IC was significantly rare in the group born after 40 weeks in our study, while other studies showed no relationship with IC and gestational age ${ }^{26}$. Passing meconium in the delivery room was mostly observed in neonates without IC, which may support our thesis. Additionally, neonates with IC had fewer defecations in the first $72 \mathrm{~h}$ of life. Both of these situations may indicate hypomotility of the gut in colicky infants. In evaluation of feeding methods, breastfeeding was less frequent as a first feeding type in neonates with IC than in others in the present study. Additionally, our results showed that the number of breastfed infants during the first 3 months of life was significantly lower in the IC group. Previous studies had examined the effect of nutrition on IC, and while some showed no association with feeding methods and IC ${ }^{30}$, in some other studies, breastfeeding had been noted as the main protective factor for IC ${ }^{29}$.

There are some limitations to this study. The medical hypotheses for the pathogenesis of IC include food hypersensitivity or allergy; the behavioral hypotheses include inadequate maternal-infant interaction, anxiety in the mother, and difficult infant temperament; and other recent hypotheses include hormone alterations and maternal smoking. These hypotheses were not studied in our study. Formula type was not recorded. In addition, the size of our study population may be relatively small.

\section{CONCLUSION}

Although the etiology of IC is still unclear, our findings showed that neonates who do not have their first meconium in the first $5.8 \mathrm{~h}$ after birth, and who have fewer than 17 defecations in the first $72 \mathrm{~h}$ of life, are at risk of IC development. The present study is the first report to estimate the effects of the ToFM and number of stool in the first $72 \mathrm{~h}$ upon the IC. These results will be a guide for subsequent larger-scale studies on this subject.

\section{REFERENCES}

1. Clark DA. Times of firstvoidandfirststool in 500 newborns. Pediatrics 1977; 60: 457-9.

2.Loening-Baucke V, Kimura K. Failuretopassme conium: Diagnosingneonatalintestinalobstruction. AmFamPhysician 1999;60:2043-50.

3.Wang PA, Huang FY. Time of thefirstdefecationandurination in verylow birthweightinfants. Eur $J \quad$ Pediatr 1994;153(4):279-83.

4. Wessel M, Cobb J, Jackson E, Harris GS Jr, Detwiler AC. ParoxysmalFussing in InfancySometimesCalledColic. Pediatrics 1954; 14(5): 421-434.

5. Savino F. Focus on infantilecolic. ActaPaediatr 2007; 96(9):1259-64.

6. Miller AR, Barr RG. Infantilecolic. Is it a gut issue? Pediatr Clin North Am 1991; 38(6):1407-23.

7. Barr RG. Colicandcryingsyndromes in infants. Pediatrics 1998; 102:1282-6.

8. Landgren K, Raith W, Schmölzer GM, Skjeie H, Skonnord T. Acupuncture in thetreatment of infantilecolic. Ital J Pediatr 2015;41:1. doi: 10.1186/s13052-014-0105-3.

9. Savino F, Ceratto S, De Marco A, CorderodiMontezemolo L. Lookingfornewtreatments of InfantileColic. Ital J Pediatr 2014; 40:53.

10. Metcalf TJ, Irons TG, Sher LD, Young PC. Simethicone in thetreatment of infantcolic: a randomized, placebocontrolled, multicentertrial. Pediatrics 1994; 94:29-34.

11. Anabrees J, Indrio F, Paes B, AlFaleh K. Probioticsforinfantilecolic: a systematicreview. BMC Pediatr 2013;13:186.

12. Garza-Cox S, Keeney SE, Angel CA, Thompson LL, Swischuk LE. Meconiumobstruction in theverylowbirthweightprematureinfant. Pediatrics 2004;114(1):285-90.

13. Ghosh S, Barr RG. Colicandgas. In: Walker WA, Goulet O, Kleiman RE, et al, eds. PediatricGastrointestinalDisease. 4th ed. Hamilton, Ontario: BC DeckerInc; 2004. p. 210. 
14. Crowcroft NS, Strachan DP. Thesocialorigins of infantilecolic: questionnairestudycovering 76,747 infants. BMJ 1997;314: 1325-8.

15.Savino F, Grassino EC, Guidi $C$ et al. Ghrelinandmotilinconcentration in colickyinfants. ActaPaediatr 2006; 95(6):738-41.

16. Bekkali N, Hamers SL, SchipperusMR et al. Duration of meconiumpassage in pretermandterminfants. ArchDis Child FetalNeonatalEd 2008; 93(5):F376-9.

17. Okoro PE, Enyindah CE. Time of passage of First Stool in Newborns in a TertiaryHealthFacility in SouthernNigeria. Niger J Surg 2013; 19(1):202.

18. Chih TW, Teng RJ, Wang CS, TsouYau KI. Time of thefirsturineandthefirststool in Chinesenewborns. ZhonghuaMinGuoXiao Er Ke YiXueHuiZaZhi 1991; 32(1):17-23.

19. Jhaveri MK, Kumar SP. Passage of thefirststool in verylowbirthweightinfants. Pediatrics 1987; 79(6):1005-7.

20. Weaver LT, Lucas A. Development of bowelhabit in preterminfants. ArchDis Child 1993; 68:317-20.

21. Brand PL, Molenaar NL, Kaaijk C, Wierenga WS. Neurodevelopmentaloutcome of hypoglycaemia in healthy, largeforgestationalage, termnewborns. ArchDis Child 2005;90:78-81.

22. Verma A, Dhanireddy R. Time of firststool in extremelylowbirthweight $(<$ or $=1000$ grams $)$ infants. J Pediatr 1993; 122:626-9.
23. Tateishi H, Yamauchi Y, Yamanouchi I, Khshaba MT. Effect of mode of delivery, parityandumbilicalbloodgas

on firstmeconiumpassage in fulltermhealthyinfants. BiolNeonate 1994; 66:146-9.

24. Metaj M, Laroia N, Lawrence RA, Ryan RM. Comparison of breast- andformula-fed normal newborns in time tofirststoolandurine. J Perinatol 2003; 23(8):624-8.

25. Lucassen PLBJ, Assendelft WJ, vanEijk JT et al. Systematicreview of theoccurrence of infantilecolic in thecommunity. ArchDis Child 2001; 84: 398-403.

26. Talachian E, Bidari A, Rezaie MH. Incidenceand risk factorsforinfantilecolic in Iranianinfants. World J Gastroenterol 2008; 14(29): 4662-6.

27. Sondergaard C, Skajaa E, Henriksen TB. Fetalgrowthandinfantilecolic. ArchDis Child FetalNeonatalEd 2000; 83: F44-7.

28. Milidou I, Søndergaard C, Jensen MS, Olsen J, Henriksen TB. Gestationalage, smallforgestationalage, andinfantilecolic. PaediatrPerinatEpidemiol 2014; 28(2):138-45.

29. Saavedra MA, da Costa JS, Garcias Get al. Infantilecolicincidenceandassociated risk factors: a cohortstudy. J Pediatr (Rio J) 2003; 79(2):115-22.

30. Clifford TJ, Campbell MK, Speechley KN, Gorodzinsky F. Infantcolic: empiricalevidence of theabsence of an associationwithsource of earlyinfantnutrition. Arch Pediatr AdolescMed 2002; 156:1123-8. 